\title{
Callus Induction and Indirect Regeneration of Strawberry (Fragaria $\times$ Ananassa) Duch. CV. Chandler
}

\author{
Suvalaxmi Palei ${ }^{1 *}$, G.R. Rout ${ }^{2}$, A.K. Das ${ }^{1}$ and D.K. Dash ${ }^{1}$ \\ ${ }^{1}$ Department of Fruit Science and Horticulture Technology, ${ }^{2}$ Department of Agricultural \\ Biotechnology, College of Agriculture, Orissa University of Agriculture and Technology, \\ Bhubaneswar, Odisha, India \\ *Corresponding author
}

\section{A B S T R A C T}

An experiment on callus induction and indirect regeneration of strawberry cv. Chandler was conducted by taking different explants (internodal cuttings, matured leaves, young leaves, flower buds) were cultured on MS medium supplemented with different growth regulators and incubated in culture room for callus induction. Expansion and swelling of explants at the cut surface were noted and soft crystal, greenish compact calli were

\section{Keywords}

Strawberry, Callus, Plant growth regulators.

Article Info

Accepted:

12 September 2017 Available Online: 10 November 2017 emerged from the cut surface within 3-4 weeks culture on MS medium supplemented with 2, 4- D (1.0 mg/l) along with BAP $(0.1 \mathrm{mg} / \mathrm{l})$. Also same medium resulted the highest callus induction $(170.6 \mathrm{mg})$ along with $90 \%$ callus induction frequency. Healthy calli were taken in a sterile petridish and chopped into small pieces with a fresh weight of approximately 100 - $120 \mathrm{mg}$, then inoculated on shoot regeneration medium containing different concentration of BAP $(0.5,1.0,1.5,2.0,2.5$ and $3.0 \mathrm{mg} / \mathrm{l})$ and NAA $(0.2$ and 0.5 $\mathrm{mg} / \mathrm{l})$. Green shoot primordia developed on the surface of calli within 4-5 weeks. The number of shoots formed per callus was investigated after 30 days of culturing. BAP @ $2.5 \mathrm{mg} / 1$ and NAA @ $0.5 \mathrm{mg} / \mathrm{l}$ with the basal MS media showed the maximum response to regeneration via calli inducing an average of 5.1 shoot buds per culture within 4-5 weeks. Regenerated shoots were then transferred to MS medium with BAP and NAA for shoot multiplication and subsequent induction of best roots. The maximum percentage of rooting was observed in half strength MS media supplemented with $0.25 \mathrm{mg} / \mathrm{l} \mathrm{IBA}$ and $2 \%$ sucrose. The developed plantlets through in vitro culture technique were acclimated and successfully transferred to in vivo condition for further evaluations. Analysis was carried out in completely randomized design with three replications for each treatment.

\section{Introduction}

"Fragaria" belongs to family Rosaceae, is a genus of the perennial, creeping herbs, found growing in the wild in different climatic zones of the world (1). The cultivated strawberry (Fragaria $\times$ ananassa Duch.) is a monoecious octaploid hybrid of two largely dioecious octaploid species, Fragaria chiloensis Duch. and Fragaria virginiana
Duch. $(2,3,4)$. It contains vitamin A, vitamin $\mathrm{E}$ and health promoting flavonoid polyphenolic antioxidants such as lutein, zeaxanthin, and beta-carotene in small amounts. These compounds act as protective scavengers against oxygen-derived free radicals and reactive oxygen species (ROS) that play a role in aging and various disease 
processes. Strawberries are known for their characteristics aroma, which is attributed to the presence of volatile ester. It is produced in 73 countries worldwide on 200,000 hectare area and produced 31 lakh metric tons strawberry (5). It has been commercially cultivated in Canada, USA, Japan, Spain, Germany, Korea, Italy, Poland, Thailand and so many countries in the world(6). But it is cultivated in India in very small scale, so that propagation, production of strawberry need a great attention of scientists as well as policy maker.

Propagation of strawberry, through seed is easier, but the plants are not true to type. Large numbers of seed per fruit as compared to other fruit crops but seeds are very small and required stratification, the effective chilling temperature ranges from -2 to $6.5^{\circ} \mathrm{C}(7,8,9)$ and duration of chilling period is usually 2-4 weeks (4).Strawberry plants also spread vegetatively using runners and this enables them to be easily transplanted and propagated as clones but the major problem is that strawberries are affected by over 30 viruses and phytoplasmas, many of which can greatly reduce yield, rapidly spread in the field, and may not cause obvious symptoms, so micropropagation is the first major and widely accepted practical application of plant biotechnology that has gained the status of a multibillion dollar industry throughout the world by providing disease free true to the type propagating material.

Tissue culture is the in-vitro aseptic culture of cells, tissues, organs or whole plant under controlled nutritional and environmental conditions often to produce the clones of plants. The resultant clones are true-to type of the selected genotype (10). The controlled conditions provide the culture an environment conducive for their growth and multiplication. These conditions include proper supply of nutrients, $\mathrm{pH}$ of medium, adequate temperature and proper gaseous and liquid environment. Plant tissue culture technology is being widely used for large scale plant multiplication. Apart from their use as a tool of research, plant tissue culture techniques have in recent years, become of major industrial importance in the area of plant propagation, disease elimination, plant improvement and production of secondary metabolites. Commercial production of plants through micropropagation techniques has several advantages over the traditional methods of propagation through seed, cutting, grafting and air-layering etc. It is rapid propagation processes that can lead to the production of virus free plants (11). In vitro regeneration technique in strawberry has been standardized (12).Different explants like meristem tip, anthers, immature embryos and first axillary buds of stolon have been used to produce millions of plants in the year $(13,14$, $15,16)$. On the above fact, the present investigation was carried out on callus induction and indirect regeneration of strawberry cv. Chandler was conducted by taking different explants (internodal cuttings, matured leaves, young leaves, flower buds) were cultured on MS medium supplemented with different growth regulators and incubated in culture room for callus induction.

\section{Materials and Methods}

For the above said experiment, the explants (young and mature leaves, internodes) of Strawberry were collected from Fruit Research Station, Orissa University of Agriculture and Technology, Bhubaneswar, Odisha. Then the explants were washed first under running tap water for 30 minutes and treated with $1 \%$ v/v Tween 20 for ten minutes followed by repeated rinsing with sterile distilled water. Further sterilization was done under aseptic condition in laminar air flow cabinet. Explants were surface sterilized with $50 \%(\mathrm{v} / \mathrm{v})$ ethyl alcohol $(1 \mathrm{~min})$ followed by 
$0.1 \%(\mathrm{w} / \mathrm{v}) \mathrm{HgCl}_{2}$ (7 min). Finally, the explants were washed thoroughly (five times) with sterilized distilled water and cut into appropriate size $(1.5 \mathrm{~cm})$ and cultured on MS medium supplemented with $1.5 \mathrm{mg} / \mathrm{l} \mathrm{BA}+$ $0.1 \mathrm{mg} / \mathrm{l} \mathrm{NAA}$ adding $30 \mathrm{~g} / \mathrm{l}$ sucrose and $0.6 \%$ agar (BDH, England). The $\mathrm{pH}$ of the medium was adjusted to 5.7 before autoclaving at 1.06 $\mathrm{kg} / \mathrm{cm} 2$ and $121^{\circ} \mathrm{C}$ for $20 \mathrm{~min}$. The cultures were incubated in growth chamber16/8 light/dark cycle at $25 \pm 2{ }^{\circ} \mathrm{C}$ for shoot proliferation. Then the leaves and internode from proliferated multiple shoots were cut into small segments $(0.5-1.0 \mathrm{~cm})$ and notched by scalpel in laminar air flow and cultured on a semi-solid MS medium supplemented with different concentrations and combinations of BAP, NAA and 2,4-D for callus induction and then the cultures were incubated in dark around 30 days for callus induction.

Plantlets were regenerated by transferring the selected calli in MS semisolid medium supplemented with different formulations of BAP and NAA. Then each callus body was investigated irrespective of number of shoot initiated. Percentage of plants per explants were calculated and defined as shooting efficiency. The regenerated shoots were excised and subcultured on MS media supplemented with different concentration of NAA and IBA for further shoot and root growth.

Well rooted plantlets were transferred in soil for acclimatization. The experiments were designed and analyzed according to completely randomized design. For each treatment, 20 explants were cultured and the experiment was replicated thrice. The morphogenic potential of tissues was evaluated by analyzing morphological parameters of the structures formed on explants. The evaluation was based on the relative frequency of callus producing shoots (\%) as well as the average number of shoots per explant. Mean values and standard error of mean (SE) for each treatment were calculated.

\section{Results and Discussion}

Callus refers to a mass of unorganized parenchymatous cells derived from plant tissue. The tissues used to initiate callus formation depend on plant tissues and growth hormone used. Generally, a higher auxins concentration in growth medium induces callus formation. The quality and quantity of callus mass depends on various factors like explants, plant growth regulators and light/dark incubation etc. Among different growth regulators BAP and 2, 4-D were found to be most suitable for callus induction in strawberry.

However, the effect of different plant growth regulator formulations on the degree and types of callus formation were different. Highest $(90 \%)$ callus induction was noted in $1.0 \mathrm{mg} / 1$ 2, 4-D + $0.1 \mathrm{mg} / \mathrm{l}$ BAP supplemented medium using internodal derived explants. The calli were green in colour and mostly compact in nature but few were loosely compact in texture and the similar result was found by Akter et al., (17). Callus induction is a pre-requisite on the way to generate somaclonal variation. Because during callus division in artificial conditions different types of abnormalities occur in the genetic constituents that ultimately contributed to the regenerated plants $(18,19)$. As a result, a lot of variation may be found in the plants regenerated from a single callus population. Callus formation is controlled by the level of plant growth regulators (auxins and cytokinins) in the culture medium. Concentrations of plant growth regulators can vary for each plant species and can even depend on the source of explant or individual plant. Culture conditions (temperature, light and photoperiod etc.) are also important. 
Cultures will be used to study protoplast isolation, cell type, cellular selection, somatic embryogenesis, organogenesis and secondary metabolites production. Protocols in previous studies have shown that plant growth regulators concentrations and selections are vital for strawberry callus induction and regeneration. Various formulations of BAP, IBA, 2,4-D, Kn, NAA, TDZ, $\mathrm{CH}$, and $\mathrm{KNO}_{3}$, all have been reported using in callus induction and plant regeneration studies in strawberry (20, 21, 22). Liu and Sanford (20) reported the use of casein hydrolysate $(\mathrm{CH})$ and potassium nitrate on leaf explants of 'Allstar' strawberry. Both stimulated the production of callus and shoot and reportedly had an additive effect. Best callus and shoot production in their study was achieved with a combination of BAP, IBA, $\mathrm{CH}$, and $\mathrm{KNO}_{3}$. Kartha et al., (23) successfully regenerated 'Redcoat' using a combination of BAP, IBA and $\mathrm{GA}_{3}$ as a precursor to a cryopreservation study of the cultivars.

In the present investigation auxin in combination with cytokinin was found the most effective for callus induction, which is concomitant with most of the previous report (Table 1). Notable amount of callus induction was observed in media having $2.5 \mathrm{mg} / \mathrm{l} \mathrm{NAA}$ $+0.5 \mathrm{mg} / \mathrm{l} \mathrm{BAP}$ from internodal explants. The calli were green and compact. The result illustrated that the internodal explants were best for maximum callus induction than young leaf and mature leaf explants. However Mature leaf explants were favourable for callus induction and shoot regeneration more than young leaves and internode in all case (24). Hamnoudeh et al., (25) achieved regenerated plantlets of Honeoye strawberry from the auxiliary buds by culturing for 4 weeks on MS medium supplemented with BAP $(2.5 \mathrm{mg} / \mathrm{l})$ and thiazuron $(5.5 \mathrm{mg} / \mathrm{l})$ with vitamins for shoot proliferation. Ara et al., (26) found best response in callus induction of strawberry on MS media with $1.0 \mathrm{mg} / 1$ 2,4-D $+0.1 \mathrm{mg} / \mathrm{l}$ BAP, 2 weeks after culture. Maximum number of multiple shoots regenerated in MS medium supplemented

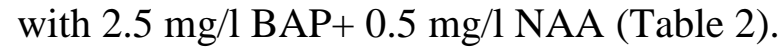

The healthy microshoots were separated from the clump and transferred to different medium having various concentrations of auxins with $2 \%(\mathrm{w} / \mathrm{v})$ sucrose for induction of rooting. No rooting was observed in basal full strength or half strength MS media without growth regulators. The maximum percentage of rooting was observed in half strength MS media supplemented with $0.25 \mathrm{mg} / \mathrm{l} \mathrm{IBA}$ and $2 \%$ sucrose. The medium supplemented with NAA also favoured the induction of rooting but the efficiency was more in IBA containing medium. The higher percentage of rooting was $73.3 \%$ in case of Fragaria $\times$ ananassa Duch. cv. Chandler. For in vitro rooting of plantlets of Hofla and Tangi strawberry, Pereira et al., (27) had reported that $3 / 4^{\text {th }}$ to $1 / 2$ strength salts of MS medium were better than full concentration (Table 3).

Regenerated shoots $(<4 \mathrm{~cm})$ started root initiation within 20 days of inoculation when they were cultured half strength of MS medium added with different concentrations of NAA and IBA individually. All treatments induced roots, but maximum rooting $(73.3 \%)$ and vigorous growth of plantlets were observed on MS media within 20 days of inoculation. The highest mean number of roots $(4.5 \pm 0.6)$ was recorded in the media containing $0.25 \mathrm{mg} / \mathrm{l} \mathrm{IBA}$ in $1 / 2 \mathrm{MS}$ medium. Addition of auxin in rooting media accentuates rooting but also microcuttings developed callus at their base that hamper their field establishment. Similar results on the rooting and subsequent field establishment were also reported by several researchers (4, 24, 28, 29). 
Table.1 Effect of plant growth regulators on callus induction of Fragaria $\times$ ananassa Duch. cv. Chandler

\begin{tabular}{|c|c|c|c|c|c|c|c|}
\hline \multicolumn{3}{|c|}{$\begin{array}{c}\text { Treatments } \\
\text { MS + Growth } \\
\text { Regulators (mg/l) }\end{array}$} & \multirow{2}{*}{$\begin{array}{l}\text { Weight of } \\
\text { callus after } \\
30 \text { days ( } \mathbf{m g} \text { ) }\end{array}$} & \multirow{2}{*}{$\begin{array}{c}\text { Callus } \\
\text { induction } \\
\text { frequency } \\
(\%)\end{array}$} & \multicolumn{3}{|c|}{ Colour and nature of growth } \\
\hline 2,4-D & BAP & NAA & & & $\begin{array}{c}\text { Matured } \\
\text { Leaves }\end{array}$ & Young Leaves & $\begin{array}{l}\text { Internodal } \\
\text { cuttings }\end{array}$ \\
\hline 0.5 & 0.5 & 0 & 0.0 & 00 & $\begin{array}{l}\text { Light Green } \\
\text { Compact }\end{array}$ & $\begin{array}{l}\text { Light Green } \\
\text { Compact }\end{array}$ & $\begin{array}{l}\text { Light Green } \\
\text { Compact }\end{array}$ \\
\hline 1.5 & 0.5 & 0 & $29.0 \pm 0.2 \mathrm{a}$ & $30.0 \pm 0.1 \mathrm{a}$ & $\begin{array}{c}\text { Green } \\
\text { Compact }\end{array}$ & $\begin{array}{c}\text { Green } \\
\text { Compact }\end{array}$ & $\begin{array}{c}\text { Light Green } \\
\text { Compact }\end{array}$ \\
\hline 2.0 & 0.5 & 0 & $50.7 \pm 0.6 \mathrm{~b}$ & $50.0 \pm 0.4 \mathrm{~b}$ & $\begin{array}{c}\text { Green } \\
\text { Compact }\end{array}$ & $\begin{array}{c}\text { Green } \\
\text { Compact }\end{array}$ & $\begin{array}{c}\text { Light Green } \\
\text { Compact }\end{array}$ \\
\hline 2.5 & 0.1 & 0 & $92.4 \pm 0.5 \mathrm{c}$ & $60.0 \pm 0.6 \mathrm{c}$ & $\begin{array}{c}\text { Green } \\
\text { Loosely } \\
\text { Compact }\end{array}$ & $\begin{array}{l}\text { Light Green } \\
\text { Loosely } \\
\text { Compact }\end{array}$ & $\begin{array}{c}\text { Light Green } \\
\text { Compact }\end{array}$ \\
\hline 1.0 & 0.1 & $\mathbf{0}$ & $170.6 \pm 0.4 f$ & $90.0 \pm 0.2 \mathrm{e}$ & $\begin{array}{c}\text { Green } \\
\text { Compact }\end{array}$ & $\begin{array}{c}\text { Green } \\
\text { Compact }\end{array}$ & $\begin{array}{c}\text { Green } \\
\text { Compact }\end{array}$ \\
\hline 0 & 0.5 & 2.0 & $142.9 \pm 0.9 \mathrm{e}$ & $70.0 \pm 0.7 \mathrm{~d}$ & $\begin{array}{l}\text { Green } \\
\text { Friable }\end{array}$ & $\begin{array}{l}\text { Creamy Green } \\
\text { Compact }\end{array}$ & $\begin{array}{l}\text { Light Green } \\
\text { Compact }\end{array}$ \\
\hline 0.5 & 0 & 1.0 & $112.6 \pm 0.2 \mathrm{~d}$ & $60.0 \pm 0.8 \mathrm{c}$ & $\begin{array}{l}\text { Creamy } \\
\text { Friable }\end{array}$ & Creamy Friable & $\begin{array}{l}\text { Creamy } \\
\text { Friable }\end{array}$ \\
\hline
\end{tabular}

N.B.- Medium used- Murashige and Skoog (MS) medium

*20 cultures per treatment; replicated thrice

Mean followed by different letters are significantly different at the 5\% level. (Post-hoc multiple comparison test, $\mathrm{p}=0.05$

Table.2 Effect of plant growth regulators BAP and NAA on the indirect regeneration of Fragaria $\times$ ananassa Duch. cv. Chandler after 4 weeks of culture

\begin{tabular}{|c|c|c|c|}
\hline \multicolumn{2}{|c|}{$\begin{array}{c}\text { Treatments } \\
\text { MS + Growth Regulators } \\
\text { (mg/l) }\end{array}$} & \multirow{2}{*}{$\begin{array}{c}\text { No. of shoots } \\
\text { regenerated per } \\
\text { callus }\end{array}$} & $\begin{array}{c}\text { Regeneration } \\
\text { frequency (\%) }\end{array}$ \\
\hline BAP & NAA & $2.3 \pm 0.2 \mathrm{~b}$ & $30 \pm 0.2 \mathrm{a}$ \\
\hline 0.5 & 0.2 & $1.9 \pm 0.5 \mathrm{a}$ & $35 \pm 0.2 \mathrm{~b}$ \\
\hline 1.0 & 0.2 & $2.7 \pm 0.8 \mathrm{~b}$ & $44 \pm 0.2 \mathrm{c}$ \\
\hline 1.5 & 0.2 & $3.0 \pm 0.1 \mathrm{~b}$ & $48 \pm 0.5 \mathrm{c}$ \\
\hline 2.0 & 0.2 & $3.5 \pm 0.5 \mathrm{c}$ & $55 \pm 0.3 \mathrm{~d}$ \\
\hline 2.5 & 0.2 & $2.4 \pm 0.3 \mathrm{~b}$ & $50 \pm 0.4 \mathrm{c}$ \\
\hline 3.0 & 0.2 & $2.8 \pm 0.6 \mathrm{~b}$ & $45 \pm 0.1 \mathrm{c}$ \\
\hline 0.5 & 0.5 & $3.0 \pm 1.1 \mathrm{~b}$ & $48 \pm 0.6 \mathrm{c}$ \\
\hline 1.0 & 0.5 & $3.5 \pm 1.2 \mathrm{c}$ & $55 \pm 0.1 \mathrm{~d}$ \\
\hline 1.5 & 0.5 & $3.5 \pm 0.9 \mathrm{c}$ & $55 \pm 0.2 \mathrm{~d}$ \\
\hline 2.0 & 0.5 & $\mathbf{5 . 1} \pm \mathbf{0 . 7 d}$ & $\mathbf{6 8} \pm \mathbf{0 . 5 e}$ \\
\hline $\mathbf{2 . 5}$ & $\mathbf{0 . 5}$ & $3.0 \pm 0.3 \mathrm{~b}$ & $48 \pm 0.1 \mathrm{c}$ \\
\hline 3.0 & 0.5 & & \\
\hline
\end{tabular}

N.B.- Medium used- Murashige and Skoog (MS) medium

*20 cultures per treatment; replicated thrice

Mean followed by different letters are significantly different at the 5\% level. (Post-hoc multiple comparison test, $\mathrm{p}=0.05)$ 
Table.3 Effect of plant growth regulators (NAA \& IBA) on rooting of microshoots

\begin{tabular}{|c|c|c|c|c|}
\hline \multicolumn{2}{|c|}{$\begin{array}{l}1 / 2 \mathrm{MS}+\text { growth regulator }(\mathrm{mg} / \mathrm{l})+2 \% \\
(\mathrm{w} / \mathrm{v}) \text { sucrose }\end{array}$} & \multirow{2}{*}{$\begin{array}{c}\% \text { of response } \\
(\text { Mean } \pm \text { SE)* }\end{array}$} & \multirow{2}{*}{$\begin{array}{l}\text { No. of roots/ } \\
\text { microshoots }\end{array}$} & \multirow{2}{*}{$\begin{array}{l}\text { Days to } \\
\text { rooting }\end{array}$} \\
\hline NAA & IBA & & & \\
\hline 0 & 0 & 0.0 & - & - \\
\hline 0.25 & 0 & $23.3 \pm 0.6 \mathrm{a}$ & $2.2 \pm 0.5 \mathrm{a}$ & 28 \\
\hline 0.50 & 0 & $26.6 \pm 0.5 \mathrm{~b}$ & $2.3 \pm 0.4 \mathrm{a}$ & 26 \\
\hline 1.0 & 0 & $43.3 \pm 0.4 \mathrm{~d}$ & $3.4 \pm 0.3 \mathrm{a}$ & $25+$ \\
\hline $\mathbf{0}$ & 0.25 & $73.3 \pm 0.6 \mathrm{~g}$ & $4.5 \pm 0.6 \mathrm{~b}$ & 20 \\
\hline 0 & 0.50 & $56.6 \pm 0.7 \mathrm{f}$ & $4.2 \pm 0.5 \mathrm{~b}$ & 22 \\
\hline 0 & 1.0 & $43.3 \pm 0.6 \mathrm{c}$ & $3.4 \pm 0.6 \mathrm{a}$ & $25+$ \\
\hline 0.25 & 0.25 & $46.6 \pm 0.8 \mathrm{e}$ & $3.8 \pm 0.7 \mathrm{a}, \mathrm{b}$ & $26+$ \\
\hline
\end{tabular}

*20 replicates/treatment; repeated thrice.

+- Callusing at the basal end

Mean followed by different letters are significantly different at the 5\% level. (Post-hoc multiple comparison test, $\mathrm{p}=0.05$ )

\section{Indirect organogenesis of strawberry cv. Chandler}
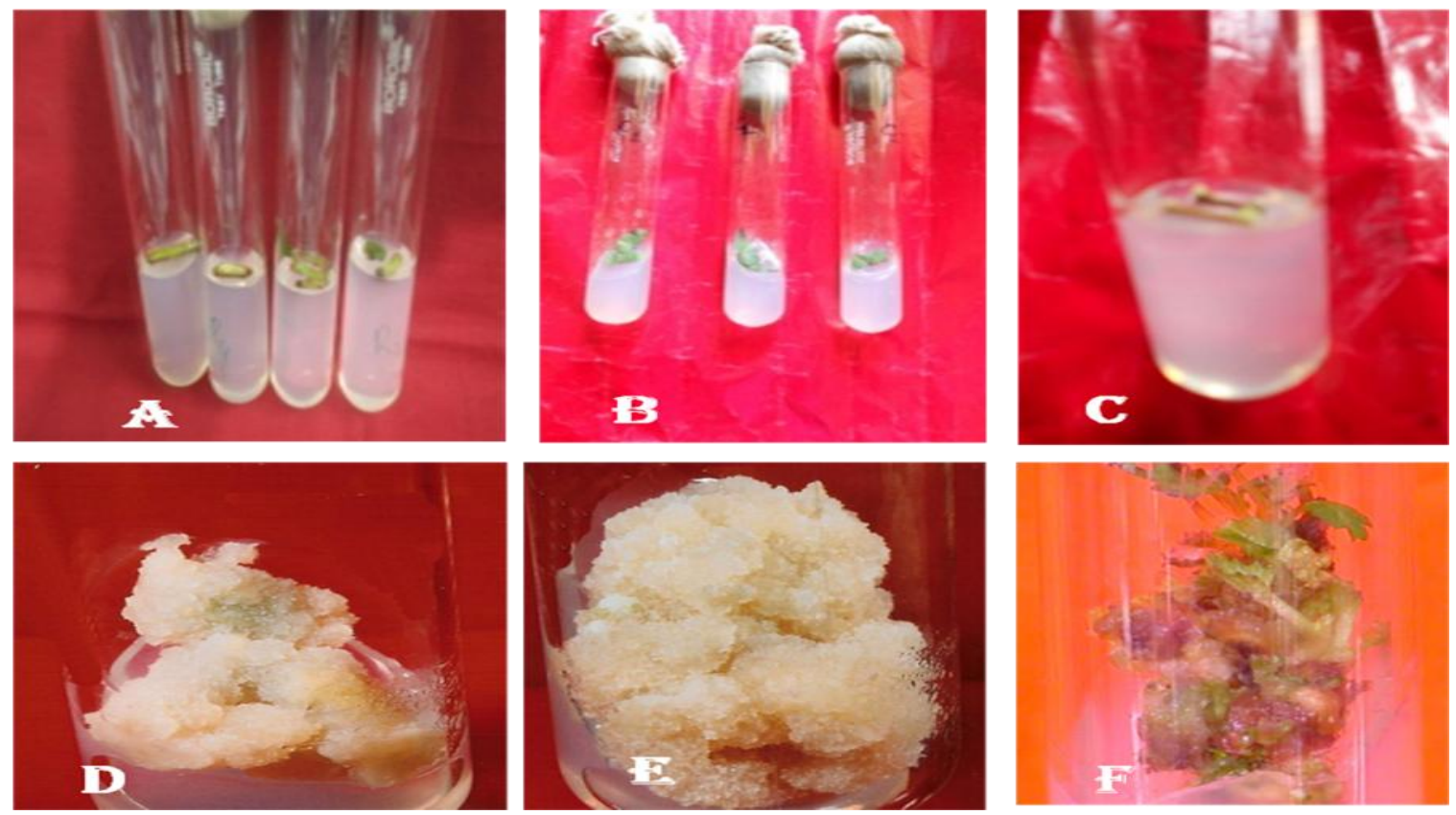

A: Innoculated internodal explant for callus induction

B: Innoculated leaf explant for callus induction

C: Initiation of callus from internodal explant after 1 week of culture

D: Callus induction after 4 weeks of culture

E: Callus induction after 5 weeks on MS medium supplemented with $1.0 \mathrm{mg} / 1$ 2,4-D and $0.1 \mathrm{mg} / \mathrm{l} \mathrm{BAP}$

F: Shoot regeneration after 4 weeks of inoculation of callus in MS medium supplemented with $2.5 \mathrm{mg} / \mathrm{l} \mathrm{BAP}$ and 0.5 $\mathrm{mg} / \mathrm{l} \mathrm{NAA}$

The protocol could be useful for successful induction of callus and regeneration of plants in strawberry to study somaclonal variation and improvement of variety. Micro- propagation techniques are becoming important for mass cloning of many economical plant species because of the uniformity and potential for planned 
production. Several chemical and physical factors influenced the establishment of micropropagation of plants. Significant information on the consistency of the rate of multiplication, the genetic stability of the in vitro raised plants and the success rate of establishment of the micropropagated plants in soil and their performance in the field was extremely important before adopting a technique on commercial scale.

While, it has been recognized that the propagation through tissue culture must proceed through a sequence of steps such as, (1) establishment of aseptic culture, (2) multiplication of the propagules, (3) understanding the physical and chemical factors responsible for high frequency multiplication, (4) genetic uniformity of the micropropagated plants and (5) establishment of plantlets in the soil.

In recent years, note-worthy contributions have been made by various workers on in vitro plant propagation and the findings have helped to standardize protocols for commercial propagation of a large number of plant species.

\section{Acknowledgement}

Words fail to express the sincere and deep sense of reverence to Department of Agricultural Biotechnology, Department of Fruit Science and Horticulture Technology, College of Agriculture, Orissa University of Agriculture and Technology, Odisha.

\section{References}

1. CSIR. 1956. Fragaria (In): Wealth of India, pp: 59-68. Council of scientific and industrial research, New Delhi

2. Darrow GM. 1996. The Strawberry: History, breeding and physiology, Chapter 20, Holt, Rinehart and Winston, New York.
3. Galleta GJ and Bringhrust RS. 1990. Strawberry management. (In): Small Fruit Management, chapter 3, Galleta G.J. And Mimelrick (Eds), prentice hall. Englewood cliffs, New Jersey.

4. Larson KD. 1994. Strawberry (In): handbook of environmental physiology of fruit crops. Temperate Crops, Volume 1, Pp: 271-297, Schaffer, B. and Anderson, P.C.( Eds). CRC, Press, Inc,

5. FAO (2008). FAOSTAT Agricultural Statistics Database. http:// www. Fao.org.

6. Biswas M, Hossain MB, Ahmed UK, Roy R, Karim MA , Razvy $M$ and Islam R. 2007. Multiple shoots regeneration of strawberry under various colour illuminations, American-Eurasian Journal of Scientific Research, 2 (2): 133-135.

7. Voth V and Bringhrust RS. 1958. Fruiting and vegetative response of lassen strawberry in Southern Carlifornia as influenced by nursery source, time of planting and plant chilling history, Proceeding Of American Society for Horticultural Science, 72: 186 190.

8. Takai T. 1970. Effective Temperature For chilling and interaction of chilling and photoperiod on growth and response of strawberry varieties. Bulletin of Horticulture Research Station, Morrioko, Japan, Seriries C (6): 379-382

9. Korenberg HG, Wassenaar LM and Lindeloof CPJ, Durner. 1986. Effect Of Temperature On Dormancy In Strawberry, Scientia Horticulture , 4: 361-364

10. Thorpe T. 2007. History of plant tissue culture, Journal of Molecular Microbiology and Biotechnology, 37: 169-180.

11. Garcia-Gonzales R, Quiroz K, Carrasco B and Caligari P. 2010. Plant tissue culture: Current status, opportunities and challenges, Ciencia e Investigacion Agraria. , 37(3): 530.

12. Sharma RR and Sigh SK. 1999. Strawberry cultivation- a highly remunerative farming enterprise. Agro India , 3(2): 29-31.

13. Waithaka K, Hildebrandt AC and Dana AC. 1980. Hormonal controls of strawberrt axilarry bud developement In Vitro. Journal 
Of American Society for Horticultural Science, 105(3):428-430.

14. Wang QC, Tang HR, Quan Q and Zhou GR. 1994. Phenol induced browning and establishment of shoot-tip explants of .Fuji.apple and .Jinhua. pear cultured in vitro. Journal of Horticultural Science, 69: 833-839.

15. Jones OP, Waller BJ and Beach MG. 1988. The production of strawberry plant from callus culture, Plant Cell And Organ Culture, 12: 235-241.

16. Boxus P. 1974. The production of strawberry plants by in vitro micropropagation, Journal of Horticultural Science, 49:209-210.

17. Akter F, Parvez MS, Islam MS, Mondol PC, Alam MF. 2008. Callus culture and plant regeneration in linseed (Linum usitatissimum L.), Plant Environment Developement, 2(2):101-104.

18. Larkin PJ and Scowcroft SC. 1981. Somaclonal variation - a novel source of variability from cell culture for plant improvement, Theoretical and Applied Genetics, 60: 197 - 214.

19. Shamima N, Hossain MM, Khatun A, Alam A, Mondal MR. 2003. Induction and evaluation of somaclonal variation in potato (Solanum tuberosum L.), Online Journal of Biology Science, 3(2):183-190.

20. Liu ZR and Sanford JC. 1988. Plant regeneration by organogenesis from strawberry leaf and runner tissue, Hort Science, 23: 1057-1059.

21. Nehra NS, Stushnoff C, Kartha KK. 1990. Regeneration of plants from immature leafderived callus of strawberry (Fragaria x ananassa), Plant Science, 66: 119 - 126.

22. Goffreda JC, Scopel AL, Fiola JA. 1995. Indole Butyric Acid induces regeneration of phenotypically normal apricot (Prunus armeniaca L.) plants from immature embryos, Plant Growth Regulation, 17: 41 46.

23. Kartha KK, Leung NL, Pahl K. 1980. Cryopreservation of strawberry meristems and mass propagation of plantlets, Journal of American Society for Horticultural Science, 105 (4): 481 - 484.

24. Sultana S. 2011. Induction and evaluation of somaclonal variation of strawberry (Fragaria $x$ ananassa Duch.). M. Sc. Thesis. Department of Botany, University of Rajshahi, Rajshahi-6205, Bangladesh

25. Hammoudeh HY, Suwwan MA, AbuQuooud HA and Shibli RA. 1998. MicroPropagation and regeneration of Honeoye strawberry, Dirasat agricultural sciences, 25(2): 170-178.

26. Ara T , Karim R, Karim MR, Islam R and Hossain M. 2012. Callus induction and shoot regeneration in strawberry (Fragaria $x$ ananassa Duch.), International Journal of Biosciences, 2: 93-100.

27. Pereira JES, Bianchi VJ, Dutra LF and Fortes-de-l GR. 1998.In Vitro Strawberry (Fragaria $\times$ anassa) Rooting In Different MS Medium Concentration, Cincia Rural 21(1): 17-20.

28. Owen HR, Miller AR. 1996. Haploid plant regeneration from anther cultures of three north American cultivars of strawberry (Fragaria x ananassa Duch.), Plant Cell Reports, 15:905-909.

29. Jimenez-Bermudez S, Redondo-Nevado J. 2002. Manipulation of strawberry fruit softening by antosense expression of a pectate lyase gene, Plant Physiology, 128: 751-759.

\section{How to cite this article:}

Suvalaxmi Palei, G.R. Rout, A.K. Das and Dash, D.K. 2017. Callus Induction and Indirect Regeneration of Strawberry (Fragaria $\times$ Ananassa) Duch. CV. Chandler. Int.J.Curr.Microbiol.App.Sci. 6(11): 1311-1318. doi: https://doi.org/10.20546/ijcmas.2017.611.157 